\title{
Ankylosing hyperostosis: a study of HLA A, B, and $\mathrm{C}$ antigens
}

\author{
J. D. PERRY, H. WOLF, H. FESTENSTEIN, AND G. O. STOREY
}

From the Department of Immunology, London Hospital Medical College, and Hackney Hospital, London

SUMMARY HLA A, B, and C antigens were studied in 25 patients with ankylosing hyperostosis. There was no evidence of an increased frequency of any antigen in association with the condition itself $:_{-\infty}^{\infty}$ However, a high frequency of several antigens was found, reflecting the predominance of Jewish patients in the series.

The clinical and radiological features of ankylosing hyperostosis in a series of patients seen at hospitals in the East End of London have been reviewed in this journal (Harris et al., 1974). We have now studied the HLA antigens in 25 of the 34 iases previously included. The radiological findings in these patients have confirmed the observation of previous workers that the bony bridges predominate on the right side of the spine and that spurs are more common than bridges in the cervical and lumbar regions. Cases with sacroiliitis or of other spinal disease which might cause bony bridging were excluded from the survey. Fluffy new bone formation related to the pelvis, femora, and tibiae was found in a number of cases reported.

Shapiro et al. (1976) reported the prevalence of the HLA B27 antigen in 47 white patients with ankylosing hyperostosis. They found that 16 of their patients (34\%) had the B27 antigen compared with their control figure of $8 \%$. This $34 \%$ incidence of B27 positivity, some of the radiological features already mentioned, and the lack of evidence of a continuing inflammatory reaction in this disorder led the authors to suggest that the B27 antigen might be closely associated with genes controlling new bone formation.

\section{Methods}

HLA A, B, and C typing was performed by the microlymphocytotoxic test (Festenstein et al., 1972) in the 25 patients and in 2 control groups, consisting of 60 Jewish individuals and 561 non-Jewish Caucasians.

Accepted for publication 17 April 1978

Correspondence to Dr J. D. Perry, Department of Rheumatology, London Hospital, London E1 1BB.

\section{Results}

Eighteen of the 25 patients were Jewish and mainly of Russian or Polish extraction. Only 7 patients were from the British Isles exclusively, and all stated that 6 they belonged to the Church of England. This prob- $\omega$ ably reflects the high Jewish populations in this area of London, but the possibility of an increased incidence of the disease in the Jewish population remains.

The apparent increase in the frequency of A26, B14, B16, and BW52 in Jewish hyperostotic patients ${ }^{\mathbb{D}}$ was also found in the control panel of healthy Jewish $\overrightarrow{\vec{B}}$ individuals, as can be seen in Table 1 . There was no 3 greater incidence of the HLA B27 antigen in the patients compared with the control panels, and the Jewish and Caucasian control groups showed similar frequencies of this antigen. The small number of nonJewish hyperostotic patients included does not? permit adequate interpretation in this group, although B16 was found in 2 of the 7 patients.

\section{Discussion}

It is interesting that the significant increase of $A 260$ and BW52 in the Jewish control group compared with the non-Jewish control panel is also seen in the r

Table 1 Percentage frequency of HLA antigens in ankylosing hyperostosis and controls

\begin{tabular}{|c|c|c|c|}
\hline \multirow[t]{2}{*}{ Antigen } & \multicolumn{2}{|l|}{ Jewish } & \multirow{2}{*}{$\begin{array}{l}\text { Non-Jewish } \\
\text { Caucasian } \\
\text { Controls } \\
(N=561)\end{array}$} \\
\hline & $\begin{array}{l}\text { Ankylosing } \\
\text { hypertosis } \\
(N=18)\end{array}$ & $\begin{array}{l}\text { Controls } \\
(N=60)\end{array}$ & \\
\hline $\begin{array}{l}\text { A26 } \\
\text { B14 } \\
\text { B16 } \\
\text { B27 } \\
\text { BW52 }\end{array}$ & $\begin{array}{r}22 \cdot 2 \\
22 \cdot 2 \\
38 \cdot 9 \\
5 \cdot 5 \\
22 \cdot 2\end{array}$ & $\begin{array}{r}18 \cdot 3 \\
23 \cdot 3 \\
30 \cdot 0 \\
6 \cdot 7 \\
18 \cdot 3\end{array}$ & $\begin{array}{r}4 \cdot 6 \\
10 \cdot 3 \\
7 \cdot 0 \\
8 \cdot 9 \\
1 \cdot 2\end{array}$ \\
\hline
\end{tabular}


Jewish hyperostotic patients. This highlights the need, when discussing HLA phenotype frequencies in relation to any condition, for an adequate analysis of the patients under study and inclusion of appropriate control panels.

The full phenotype frequencies found in this series do not confirm the previous reports of an increased frequency of the HLA B27 or any other antigen in patients with ankylosing hyperostosis, but the frequency of the condition in the Jewish population needs further study.

\section{References}

Festenstein, H., Adams, E., Burke, J. M., Oliver, R. T. D., Sachs, J. A., and Wolf, E. (1972). Histocompatibility Testing, pp. 175-178. Munksgaard: Copenhagen.

Harris, J., Carter, A. R., Glick, E. N., and Storey, G. O. (1974). Ankylosing hyperostosis: 1 clinical and radiological features. Annals of the Rheumatic Diseases, 33, 210-215.

Shapiro, R. F., Utsinger, P. D., Weisner, K. B., Resnick, D., Bryan, B. L., and Castles, J. J. (1976). The association of HLA B27 with Forestier's disease (vertebral ankylosing hyperostosis). Journal of Rheumatology, 3, 4-8. 